\title{
Repurposing of Drug Candidates for Treatment of Skin Cancer
}

\author{
Hernán Cortés ${ }^{1 *}$, Octavio D. Reyes-Hernández ${ }^{2}$, Sergio Alcalá-Alcalá ${ }^{3}$, \\ Sergio A. Bernal-Chávez ${ }^{4}$, Isaac H. Caballero-Florán ${ }^{4}$, Maykel González-Torres ${ }^{5}$, \\ Javad Sharifi-Rad ${ }^{6,7}$, Manuel González-Del Carmen ${ }^{8}$, Gabriela Figueroa-González ${ }^{9}$ \\ and Gerardo Leyva-Gómez ${ }^{4 *}$
}

${ }^{1}$ Laboratorio de Medicina Genómica, Departamento de Genómica, Instituto Nacional de Rehabilitación Luis Guillermo Ibarra Ibarra, Ciudad de México, Mexico, ${ }^{2}$ Laboratorio de Biología Molecular del Cáncer, UMIEZ, Facultad de Estudios Superiores Zaragoza, Universidad Nacional Autónoma de México, Ciudad de México, Mexico, ${ }^{3}$ Facultad de Farmacia, Universidad Autónoma del Estado de Morelos, Cuernavaca, Morelos, Mexico, ${ }^{4}$ Departamento de Farmacia, Facultad de Química, Universidad Nacional Autónoma de México, Ciudad de México, Mexico, ${ }^{5}$ CONACyT-Laboratorio de Biotecnología, Instituto Nacional de Rehabilitación Luis Guillermo Ibarra Ibarra, Ciudad de México, Mexico, ${ }^{6}$ Phytochemistry Research Center, Shahid Beheshti University of Medical Sciences, Tehran, Iran, ${ }^{7}$ Facultad de Medicina, Universidad del Azuay, Cuenca, Ecuador, ${ }^{8}$ Facultad de Medicina, Universidad Veracruzana, Ciudad Mendoza, Veracruz, Mexico, ${ }^{9}$ Laboratorio de Farmacogenética, UMIEZ, Facultad de Estudios Superiores Zaragoza, Universidad Nacional Autónoma de México, Ciudad de México, Mexico

Skin cancers are highly prevalent malignancies that affect millions of people worldwide. These include melanomas and nonmelanoma skin cancers. Melanomas are among the most dangerous cancers, while nonmelanoma skin cancers generally exhibit a more benign clinical pattern; however, they may sometimes be aggressive and metastatic. Melanomas typically appear in body regions exposed to the sun, although they may also appear in areas that do not usually get sun exposure. Thus, their development is multifactorial, comprising endogenous and exogenous risk factors. The management of skin cancer depends on the type; it is usually based on surgery, chemotherapy, immunotherapy, and targeted therapy. In this respect, oncological treatments have demonstrated some progress in the last years; however, current therapies still present various disadvantages such as little cell specificity, recurrent relapses, high toxicity, and increased costs. Furthermore, the pursuit of novel medications is expensive, and the authorization for their clinical utilization may take 10-15 years. Thus, repositioning of drugs previously approved and utilized for other diseases has emerged as an excellent alternative. In this mini-review, we aimed to provide an updated overview of drugs' repurposing to treat skin cancer and discuss future perspectives.

Keywords: skin cancer, drug repurposing, melanoma, nanocarriers, drug delivery systems

\section{INTRODUCTION}

Skin cancers are highly prevalent malignancies worldwide, ranked at the twentieth place of incidence $(1,2)$. There were an estimated 100,000 new melanoma cases in the United States during 2020 , with the approximate death of 6,850 people. The prevalence is higher in men, and the incidence varies according to the geographic region and by country (3). Skin cancers include melanomas and nonmelanoma skin cancers (NMSC). Melanomas are tumors that develop in 
melanocytes, and these may appear in diverse body regions. Specialists consider melanoma one of the most dangerous cancers (4). Patients in advanced stages commonly have a discouraging prognosis, and the five-year survival in those patients is $<5 \%$. Remarkably, patients without treatment exhibit a median survival between six and nine months (5). The main types of NMSC include basal cell carcinoma (BCC) and squamous cell carcinoma (SCC). NMSCs have a higher occurrence than melanoma, but they are less lethal, especially if diagnosed early (6). BBCs are skin tumors produced by the abnormal growth of basal cells. It is the most frequent type of skin cancer (7), and they are curable in many cases when detected timely. On the other hand, SCC is the second most frequent skin cancer type; it develops in the squamous cells located in the epidermis (8). SCC generally exhibits a benign clinical pattern; notwithstanding, it may sometimes be aggressive and metastatic (9).

Skin cancers develop more frequently in body regions exposed to the sun; however, they may also appear in areas that do not usually get sun exposure. Thus, their development is multifactorial, comprising endogenous (skin type and genetic factors) and exogenous (degree of sun exposure and sun protection conduct) risk factors (10). Among exogenous aspects, ultraviolet radiation (UVR) is the most notable risk factor. UVR can produce DNA damage, mutations, inflammatory responses, and oxidative stress, leading to skin cancer development (11). Among the UVR types, ultraviolet A (UVA) penetrates deeper into the skin, producing more considerable skin damage than the ultraviolet B (UVB). Nevertheless, UVB is mostly related to inflammatory responses and DNA damage as a critical tumor-promoting event (12).

Skin cancer management depends on the type; it is usually based on surgery, chemotherapy, immunotherapy, and targeted therapy $(7,9,13,14)$. In this respect, oncological treatments have demonstrated some progress in the last years; however, current therapies still present various disadvantages such as little cell specificity, recurrent relapses, high toxicity, and increased costs (14). Furthermore, the pursuit of novel medications is expensive, and the authorization for their clinical utilization may take 10-15 years (15). Thus, repositioning drugs previously approved and utilized for other diseases has emerged as an excellent alternative (16). In this mini-review, we aimed to provide an updated overview of drugs' repurposing to treat skin cancer and discuss future perspectives.

\section{DRUG REPURPOSING FOR SKIN CANCER}

Drug repurposing is the process of giving new applications for existing drugs; it may considerably diminish development costs (and times) to search for effective strategies to treat skin cancer (17). Repurposing drugs possess various advantages, including data availability about clinical tests, chemical composition, and possible toxicity, which can accelerate their application in clinical trials (18). Although various drugs have been proposed for their repurposing in skin cancer (Table 1), most of them have only been evaluated in preclinical studies, and extensive clinical trials are needed before their approval for skin cancer treatment. Nonetheless, these drugs represent a promising alternative because almost all are cheap and without significant adverse effects on therapeutic doses. Drugs that have been suggested for repositioning in skin cancer are discussed in the next sections in alphabetical order as an example of the most prominent proposals to date.

\section{Digoxin}

Digoxin is a compound utilized to treat arrhythmia and heart failure symptoms. Its mechanism of action includes inhibition of the hypoxia-inducible factor- $1 \alpha$ (HIF-1 $\alpha$ ) (42), which contributes to angiogenesis, metastasis, and tumor resistance in many cancers (43). Concerning this, Eskiocak et al. (21) suggested a therapeutic effect of digoxin against melanoma. The authors reported that digoxin exhibited low cytotoxic activity in mice xenografted with metastatic melanomas derived from patients. However, the authors found a synergistic beneficial effect when simultaneously administered with a MEK inhibitor, extending experimental mice's survival. The possible mechanism of action included acidification of cytoplasm, rises in mitochondrial $\mathrm{Ca}^{2+}$ levels, depletion of ATP, and mitochondrial function reduction. Likewise, the combination of digoxin and DMXAA (an anti-vascular agent) inhibited tumors' regrowth in mice harboring B16F10 melanoma tumors (44). The enhancement in the efficacy may be explained by the inhibition of HIF- $1 \alpha$ and stimulation of the immune function. Concerning human studies, a recent clinical trial explored the effects of parallel administration of digoxin and trametinib on BRAF wild-type metastatic melanoma patients (45). The results exposed a reasonable rate of control of disease in those patients for up ten months. Thus, this approach could be useful in metastatic melanoma patients refractory or intolerant of immunotherapy; nonetheless, additional clinical trials with a higher number of patients will be crucial.

\section{Doxycycline}

Doxycycline is a broad-spectrum tetracycline antibiotic (46). Some studies reported that doxycycline might inhibit several matrix metalloproteinases that participate in diverse cancers' metastasis (47). Thus, it has been suggested that this drug could be repositioned as an anti-cancer treatment (48). An interesting study demonstrated that doxycycline inhibited the growth of melanoma cells (49). The anti-tumor effects might be mediated by various mechanisms, including inhibition of the $N F-k B$ pathway, decrease of antiapoptotic proteins, cytochrome $\mathrm{C}$ release, and activation of caspase-8 (50). Likewise, doxycycline inhibited the adhesion and migration of a melanoma cell line, with subsequent apoptosis induction (51). This activity appeared to be mediated by inhibition of focal adhesion kinase, which participates in migration and cell adhesion regulation. Likewise, a very recent study showed that doxycycline diminished the viability and proliferation of a melanoma cell line (COLO829 cells) by decreasing intracellular levels of reduced thiols and impairing the homeostasis of the cells (22). Finally, a recently finished clinical trial found that the concomitant administration of doxycycline, temozolomide, and ipilimumab produced no 
TABLE 1 | Drugs proposed for chemoprevention and treatment of skin cancer.

\begin{tabular}{|c|c|c|c|c|}
\hline Drug & Other uses & Study model & Mechanism of action & Reference \\
\hline Albendazole & $\begin{array}{l}\text { Useful for giardiasis, trichuriasis, filariasis, } \\
\text { neurocysticercosis, among other diseases }\end{array}$ & $\begin{array}{l}\text { A375 and A2058 } \\
\text { metastatic melanoma } \\
\text { cells lines }\end{array}$ & $\begin{array}{l}\text { Induction of DNA damage and cells arrest in the G2/M phase of } \\
\text { the cell cycle, sensitizes them to radiation therapy }\end{array}$ & (19) \\
\hline Desmopressin & $\begin{array}{l}\text { Synthetic hormone commonly used for } \\
\text { nocturia and enuresis }\end{array}$ & $\begin{array}{l}\text { Mice xenografted with } \\
\text { B16-F0 melanoma cells }\end{array}$ & Modulation of proteolysis and coagulation & (20) \\
\hline Digoxin & $\begin{array}{l}\text { Antiarrhythmic agent used in heart failure, } \\
\text { and other heart disorders such as atrial } \\
\text { fibrillation }\end{array}$ & $\begin{array}{l}\text { Primary melanocytes } \\
\text { (hMEL1) or melanoma } \\
\text { cells derived from } \\
\text { patients }\end{array}$ & $\begin{array}{l}\text { Inhibits the ATP1A1 Na p/K p pump, which is highly expressed by } \\
\text { melanoma }\end{array}$ & $(21)$ \\
\hline Doxycycline & $\begin{array}{l}\text { Antibiotic used to treat infections such as } \\
\text { skin infections and rosacea. It can also be } \\
\text { used to prevent malaria }\end{array}$ & $\begin{array}{l}\text { Human (A2058 and } \\
\text { A375) and mouse } \\
\text { (B16F10) melanoma cells }\end{array}$ & $\begin{array}{l}\text { Inhibition of the MMP-2 and MMP-9 metalloproteinases activity, } \\
\text { activation of apoptosis signal-regulated kinase 1, c-Jun N-terminal } \\
\text { kinase, and caspases, which induces apoptosis }\end{array}$ & $(22,23)$ \\
\hline Fenofibrate & $\begin{array}{l}\text { Used with other medications to reduce } \\
\text { fatty substances such as cholesterol and } \\
\text { triglycerides }\end{array}$ & $\begin{array}{l}\text { Human (SkMell88) and } \\
\text { mouse (B16F10) } \\
\text { melanoma cells }\end{array}$ & $\begin{array}{l}\text { Anti-metastatic activity involving down-regulation of Akt } \\
\text { phosphorylation }\end{array}$ & $(24)$ \\
\hline Flubendazole & $\begin{array}{l}\text { Anthelmintic drug used in parasitic } \\
\text { infestations }\end{array}$ & $\begin{array}{l}\text { A375, BOWES, and } \\
\text { RPMI-7951 cells }\end{array}$ & $\begin{array}{l}\text { Anti-melanoma activity related to enhanced transcription of p53 } \\
\text { and NF-KB, as well as phosphorylation of JNK }\end{array}$ & $(25)$ \\
\hline Haloprogin & $\begin{array}{l}\text { Antifungal drug used to treat skin } \\
\text { infections such as athlete's foot }\end{array}$ & $\begin{array}{l}\text { Mouse B16F10 skin } \\
\text { melanoma tumor model }\end{array}$ & $\begin{array}{l}\text { In combination with RAPTA-T, shown to be a profitable candidate } \\
\text { for its use as a melanoma growth inhibitor through cancer cell } \\
\text { death induction }\end{array}$ & (26) \\
\hline Itraconazole & $\begin{array}{l}\text { Used to treat fungal infections as } \\
\text { aspergillosis, blastomycosis, and } \\
\text { coccidioidomycosis }\end{array}$ & $\begin{array}{l}\text { SK-MEL-28 and A375 } \\
\text { human melanoma cells }\end{array}$ & $\begin{array}{l}\text { Inhibits the proliferation and colony formation through the } \mathrm{Hh}, \mathrm{Wnt} \text {, } \\
\text { and PI3K/mTOR signaling pathways blockade }\end{array}$ & $(27)$ \\
\hline Leflunomide & $\begin{array}{l}\text { Used in active moderate-to-severe } \\
\text { rheumatoid arthritis and psoriatic arthritis }\end{array}$ & $\begin{array}{l}\text { Human melanoma cell } \\
\text { lines }\end{array}$ & $\begin{array}{l}\text { A selective inhibitor of de novo pyrimidine synthesis, blocking the } \\
\text { synthesis of DNA and RNA; reduces cell proliferation and causes } \\
\text { cells to arrest in G1 of the cell cycle. }\end{array}$ & (28) \\
\hline Lidocaine & Local anesthetic and antiarrhythmic & Human keratinocytes & $\begin{array}{l}\text { It induces membrane permeability and excessive production of } \\
\text { reactive oxygen species (ROS). }\end{array}$ & (29) \\
\hline Mebendazole & $\begin{array}{l}\text { Used to treat parasitic worm infestations } \\
\text { as ascariasis, worm infections, and } \\
\text { giardia, among others }\end{array}$ & $\begin{array}{l}\text { Human melanoma cell } \\
\text { lines }\end{array}$ & $\begin{array}{l}\text { Bcl-2 phosphorylation in melanoma cells, avoiding its interaction } \\
\text { with pro-apoptotic Bax, through apoptosis induction }\end{array}$ & (30) \\
\hline Metformin & $\begin{array}{l}\text { Commonly used to treatment of type } 2 \\
\text { diabetes, also used in the treatment of } \\
\text { polycystic ovary syndrome }\end{array}$ & $\begin{array}{l}\text { Human melanoma cell } \\
\text { lines }\end{array}$ & $\begin{array}{l}\text { Induces cell cycle arrest in the G0-G1 phase, and it's responsible } \\
\text { for autophagy and apoptosis induction }\end{array}$ & $(31,32)$ \\
\hline Naproxen & $\begin{array}{l}\text { Used to treat pain, menstrual cramps, } \\
\text { inflammatory diseases such as } \\
\text { rheumatoid arthritis, and fever }\end{array}$ & Mice irradiated with UVB & $\begin{array}{l}\text { Reduction in the incidence of tumor lesions by naproxen may be } \\
\text { due to its ability to increase TNF-a levels and decrease PGE2. }\end{array}$ & (33) \\
\hline Niclosamide & $\begin{array}{l}\text { Anti-helminthic drug, has been used to } \\
\text { treat tapeworm infection }\end{array}$ & $\begin{array}{l}\text { In vitro: human and } \\
\text { mouse melanoma cell } \\
\text { lines. } \\
\text { In vivo: a mouse } \\
\text { xenograft model of A375 } \\
\text { cell line }\end{array}$ & $\begin{array}{l}\text { Induces cell apoptosis via the mitochondrial-mediated apoptotic } \\
\text { pathway, also inhibits tumor growth by decreasing the expression } \\
\text { of p-STAT3, MMP-2, and MMP-9 }\end{array}$ & (34) \\
\hline Nicotinamide & $\begin{array}{l}\text { Treatment and prevention of niacin } \\
\text { deficiency and certain conditions related } \\
\text { such as pellagra }\end{array}$ & Human keratinocytes & $\begin{array}{l}\text { Chemopreventive effects, replenishes cellular ATP after UV } \\
\text { irradiation, and enhancement of DNA repair in UV-irradiated } \\
\text { human skin }\end{array}$ & $(35)$ \\
\hline Pimozide & $\begin{array}{l}\text { Decreasing the activity of a natural } \\
\text { substance (dopamine) in the brain, } \\
\text { Tourette syndrome patients }\end{array}$ & B16 cell-bearing mice & $\begin{array}{l}\text { Antitumor activity via the regulation of proliferation, apoptosis, and } \\
\text { migration }\end{array}$ & $(36)$ \\
\hline Piroxicam & $\begin{array}{l}\text { Used to the treatment of rheumatoid } \\
\text { arthritis and osteoarthritis, acute } \\
\text { musculoskeletal disorders, and } \\
\text { dysmenorrhea }\end{array}$ & $\begin{array}{l}\text { Patients affected by } \\
\text { Actinic keratoses }\end{array}$ & $\begin{array}{l}\text { A non-selective NSAID* that inhibits the activity of COX-1 and } \\
\text { COX-2, inducing apoptosis and inhibit recruitment and production } \\
\text { of growth factors and other carcinogenetic mediators }\end{array}$ & $(37,38)$ \\
\hline Propranolol & $\begin{array}{l}\beta \text {-blocker commonly used for high blood } \\
\text { pressure }\end{array}$ & Patients with melanoma & Inhibition of angiogenesis and migration of cancer cells & (39) \\
\hline Rafoxanide & $\begin{array}{l}\text { Anthelmictic used mainly for the treatment } \\
\text { of fasciola hepatica }\end{array}$ & $\begin{array}{l}\text { A375 and A431 cells and } \\
\text { mice xenografted with } \\
\text { those cells }\end{array}$ & $\begin{array}{l}\text { Inhibition of CDK4/6, increase of cell apoptosis, and arrest of cell } \\
\text { cycle }\end{array}$ & $(40)$ \\
\hline Telmisartan & $\begin{array}{l}\text { Angiotensin receptor } 1 \text { inhibitor widely } \\
\text { used as an antihypertensive drug }\end{array}$ & $\begin{array}{l}\text { Human melanoma cells } \\
\text { A375, 518a2, and } \\
\text { HTB140 }\end{array}$ & $\begin{array}{l}\text { Induction of apoptosis, generation of reactive oxygen species, and } \\
\text { alteration of cell bioenergetics }\end{array}$ & $(41)$ \\
\hline
\end{tabular}

*NSAID, Non-Steroidal Anti-Inflammatory Drugs. 
significant clinical improvement in patients with melanoma (NCT01590082). Although this finding could appear disappointing, preclinical studies suggest a therapeutic usefulness of doxycycline and warrant further clinical trials.

\section{Fenofibrate}

Fenofibrate is an agonist of the peroxisome proliferator-activated receptor- $\alpha$; it is indicated for managing mixed dyslipidemia and hypertriglyceridemia (52). A variety of studies have reported that fenofibrate exerts anti-tumor activities in several cancers $(53,54)$, including melanoma $(55,56)$. Panigraphy et al. (56) exposed that fenofibrate significantly inhibited the proliferation of melanoma cells (B16-F10 cells) and suppressed primary tumors' growth in vivo in a murine model. Those effects were mediated by the inhibition of inflammation and angiogenesis in the surrounding host tissue. Additionally, fenofibrate significantly decreased melanoma metastases when administered via oral in mice, suggesting that this compound possesses chemopreventive activity (55). Interestingly, a down-regulation in the phosphorylation of Akt might explain this anti-metastatic effect (24). Finally, a very recent study proposed that the effects of fenofibrate on growth and metastases of melanoma could be produced by inhibiting the TLR4-dependent signaling pathway (57). Despite the studies suggesting beneficial effects of fenofibrate in melanoma, currently, there are no ongoing clinical trials; thus, this drug perhaps requires additional studies in animal models before its evaluation in patients.

\section{Flubendazole}

Flubendazole is an anthelmintic compound (58); its mechanism of action depends on the disruption of microtubules' structure and function. This activity attracted considerable interest in the drug as a possible anti-cancer treatment (59); thus, recent studies explored the therapeutic potential of flubendazole against skin cancer $(25,60)$. For example, a pioneering study conducted by Ćánová et al. (25) demonstrated inhibition of cell growth and proliferation in three distinct types of melanoma cell lines (A375, BOWES, and RPMI-7951), finally leading to caspase-dependent apoptosis. A subsequent report demonstrated that these effects were related to enhanced transcription of p53 and NF-kB and phosphorylation of JNK, eventually producing cell cycle arrest and disturbances of the microtubules network (61). Likewise, another study reported that flubendazole suppressed tumor growth and prevented metastasis in mice with xenografts of human melanoma cells (60). According to the authors, those anti-tumor activities were produced by a decrease in STAT3 and PD-1 levels. This drug is not being evaluated in any clinical trial, so its application may need further evaluations in cellular and animal models.

\section{Itraconazole}

Itraconazole is an antimycotic drug commonly utilized worldwide, which has demonstrated the therapeutic potential for skin cancer treatment. In this regard, Kim et al. (62) revealed that itraconazole suppressed the growth of BCC in mice by inhibiting the Hedgehog signaling pathway. This exciting finding provided the foundation for a subsequent Phase II clinical trial in
BCC patients (63). The research revealed that the administration of itraconazole via oral reduced cell proliferation and tumor area; thus, the authors concluded that itraconazole possesses beneficial effects against BCC in humans. Also, Liang et al. (27) reported that itraconazole inhibited the proliferation of human melanoma cells (A735 and SK-MEL-28 cells) in vitro. Interestingly, the drug also suppressed the melanoma growth in vivo in a xenograft mice model. Further experiments revealed that the effects were mediated by suppressing Wnt, Hedgehog, and PI3K/mTOR signaling pathways. All these studies provided the basis for clinical trials. In this regard, three clinical trials are studying the effects of itraconazole in patients with skin cancer. Two of them are focused on the molecular effects of locally applied itraconazole on the growth of BCC (NCT02120677 and NCT02735356), whereas the other one is assessing the efficacy and safety of orally administered itraconazole in patients with BBC (NCT02354261).

\section{Leflunomide}

Leflunomide is a compound utilized for the management of rheumatoid arthritis (64). This drug inhibits the enzyme dihydroorotate dehydrogenase (DHODH), which is pivotal in pyrimidine synthesis (65). Since leflunomide impedes the replication of dividing cells, it provided a rationale to propose its use in preclinical cancer studies (66). For example, White et al. (67) explored the possible benefits of utilizing leflunomide to treat skin cancer. They found that leflunomide produced a substantial reduction in melanoma development in vitro (RPM17951, A375, and Hs.294T cell lines) e in vivo (xenograft in mice). According to the authors, the inhibition of $\mathrm{DHODH}$ repressed transcription elongation of genes necessary for melanoma growth such as myc and mitf. More recent studies have provided more information about molecular targets for leflunomide. For example, O'Donnell et al. (68) stated that the anti-proliferative effects of leflunomide on A375 melanoma cells are dependent on the Aryl Hydrocarbon Receptor. A similar study found that leflunomide caused cell cycle arrest and autophagy through the phosphorylation of Ulk1 and AMPactivated protein kinase (AMPK) in A375 melanoma cells (69). Finally, another study demonstrated that the combination of leflunomide and selumetinib (an inhibitor of MEK) had a synergic effect in reducing BRAFwt and mutant melanoma cells' proliferation and growth of melanoma tumors in xenografted mice (28). Interestingly, a clinical trial intended to explore the efficacy and safety of the combination of leflunomide and vemurafenib in patients with V600 mutant metastatic melanoma was prematurely terminated due to adverse effects (NCT01611675). Therefore, despite available information about approved drugs, their possible toxicity can be a critical concern in drug repurposing when combined with other substances.

\section{Mebendazole}

Mebendazole is a drug employed to helminths infestation (70), which has also been proposed for drug repurposing in skin cancer (71). A pioneering study exposed that mebendazole produced apoptosis in melanoma cells (30). The apoptotic response was promoted by the phosphorylation of B-cell 
lymphoma 2 (Bcl-2) and the decrease in X-linked inhibitor of apoptosis $(30,72)$. Interestingly, the combination of mebendazole, temozolomide, and Bcl-2 antisense had a synergistic effect in inhibiting the growth of two melanoma cell lines (73). Likewise, the combination of mebendazole and trametinib effectively inhibited the proliferation of melanoma cells derived from patients carrying $\mathrm{NRAS}^{\text {mut }} / \mathrm{BRAF}^{\mathrm{WT}}$ and reduced their growth in xenografted mice (74). Therefore, the concomitant administration of mebendazole with other medications could be an alternative for melanoma treatment. However, this drug has not been assessed in any clinical trial with patients with skin cancer. Thus, its clinical evaluation could require further evidence from preclinical studies

\section{Metformin}

Metformin is a drug commonly used in type 2 diabetes mellitus; it reduces serum glucose levels through diverse mechanisms (75). Notably, melanoma is strongly dependent on glucose metabolism (76), and several epidemiological studies presented a relationship between the use of metformin and lower skin cancer risk (77). Concerning this, an investigation revealed that metformin inhibited tumor growth in mice xenografted with SCC cells (A431 cell line); the effect appeared to be caused by the inhibition of the mTOR and NF- $\mathrm{kB}$ signaling pathways (78). Similarly, Tomic et al. showed that metformin decreases the proliferation of melanoma cells in vitro and reduces tumor growth in vivo; those effects were mediated by a cell cycle arrest (31). In comparison, other studies suggested a variety of molecular mechanisms to explain the anti-melanoma properties of metformin, including the decrease of protein TRIB3 expression (79), upregulation of miRNAs expression (80), and induction of immune response in the tumor microenvironment (81). Furthermore, metformin prevented the development of metastasis in vitro e in vivo by activating the p53 tumor suppressor protein and AMPK (82). Besides, metformin enhanced the anti-proliferative effects of binimetinib (an inhibitor of MEK) in a model of metastatic melanoma cells (83). The molecular mechanism involves P-ERK downregulation and AMPK upregulation. Due to these preclinical pieces of evidence, various clinical studies have been undertaken. Remarkably, at least five clinical trials are ongoing exploring the therapeutic effects of metformin in skin cancer (NCT01638676, NCT01840007, NCT02143050, NCT03311308, and NCT04114136). Although metformin is being studied only as an adjuvant in all the studies.

\section{Pimozide}

Pimozide is an antagonist for dopamine receptors; it is employed to treat Gilles de la Tourette syndrome and schizophrenia (84). Additionally, pimozide has shown promising results for managing several cancers, including skin cancer (36, 85-87). An early clinical trial showed that pimozide might have beneficial effects in patients with formerly medicated metastatic melanoma (86). The possible molecular mechanism for this antimetastatic effect could be mediated by inhibition of ARPC2, a subunit of the Arp2/3 complex involved in migration and invasion (85). Moreover, preclinical studies demonstrated that the combination of pimozide with other drugs might enhance its anti-melanoma activity. For example, pimozide's simultaneous use and an inhibitor of indoleamine 2,3-dioxygenase (an enzyme that participates in melanoma tolerance) had a synergistic effect against melanoma in a mouse xenograft model (36). The authors indicated that pimozide inhibited STAT3 and STAT5, regulating tumor immunity. Likewise, Zhao et al. (87) co-administered pimozide and siRNA targeting PD-1 to mice xenografted with melanoma cells. Their results revealed an increase in the antitumor effects by inducing apoptosis and enhancing immune function. Lastly, a cutting edge study explored the anti-cancer effects of pimozide and a CpG oligodeoxynucleotide (CpG ODN) on mice xenografted with B16 cells (88). Their results revealed that the combination of those compounds suppressed the melanoma growth and extended experimental subjects' survival. Those findings were due to the induction of apoptosis, repression of invasion, and enhancement of immune response. Despite all these findings, there are no clinical trials with this drug to date. Those studies shall be necessary to support its repurposing for skin cancer.

\section{Piroxicam}

Piroxicam is a non-steroidal anti-inflammatory compound that blocks the cyclooxygenases- 1 and -2 (COX-1 and COX-2) enzymes (89). Several studies have shown that those enzymes participate in the development of actinic keratoses and SCC (90, 91); thus, piroxicam could help their prevention and treatment. In support of this hypothesis, Campione et al. (38) demonstrated that piroxicam's topical application (1\%) had beneficial effects in patients with actinic keratoses. Numerous studies combining piroxicam (0.8\%) and sunscreens (SPF 50+) have found very similar results (92-97), which suggests that piroxicam might serve as a chemopreventive agent for SCC. On the other hand, a recent study reported that piroxicam exhibited cytotoxic activity on SCC cells (A431 cell line), highlighting the drug's therapeutic potential (98). Interestingly, piroxicam had no effects on the proliferation of melanoma A375 cells (99), suggesting that its anti-cancer activity is specific for SCC. Nevertheless, this drug has not been assessed in any clinical trial with patients with SCC; thus, its clinical efficacy has not been proven yet.

\section{CONCLUSION AND PERSPECTIVES}

The development of efficacious treatments for skin cancer is costly and time-consuming; hence, old drugs' repositioning has arisen as an affordable approach. This procedure requires a thorough search through multiple dataset analyses and structure-based virtual screening to select a suitable compound for repurposing $(13,100,101)$. Moreover, extensive in vitro e in vivo analyses are necessary before undertaking clinical trials. In this respect, advances in knowledge of skin cancer cellular and molecular mechanisms have provided essential information for drug repurposing. Likewise, although clinical trial execution usually requires a long time to evidence security and efficacy, the repositioning of drugs for skin cancer will consume less time than the development of novel medications. 
Interestingly, even with the evidence for repositioning old drugs for skin cancer, to our knowledge, there is limited evidence from ongoing clinical trials. Possibly, the degree of improvement, and therefore of clinical relevance, does not support the commercial profitability of the discoveries, except for metformin with at least five clinical trial registries, one of them in phase 2. It is noteworthy that metformin, itraconazole, leflunomide, and doxycycline have been proposed as adjuvants, so possibly they would not be one of the primary and first-choice drugs. Nevertheless, the concurrent use of drugs targeting different signaling pathways may enhance their anti-cancer effectiveness, therefore extending the patients' survival and reducing the relapse risk. Also, this clinical strategy would allow lowering costs related to expensive current anti-cancer medications.

Finally, as in other drug strategies for treating cancers, pharmaceutical technology tools are necessary for adequate administration and effect at skin cancer's cellular level. In this

\section{REFERENCES}

1. Ferlay J, Colombet M, Soerjomataram I, Mathers C, Parkin DM, Piñeros M, et al. Estimating the global cancer incidence and mortality in 2018: GLOBOCAN sources and methods. Int J Cancer (2019) 144:1941-53. doi: 10.1002/ijc.31937

2. Bray F, Ferlay J, Soerjomataram I, Siegel RL, Torre LA, Jemal A. Global Cancer Statistics 2018 : GLOBOCAN Estimates of Incidence and Mortality Worldwide for 36 Cancers in 185 Countries. CA Cancer J Clin (2018) 68:394-424. doi: 10.3322/caac. 21492

3. Siegel RL, Miller KD, Jemal A. Cancer statistics, 2020. CA Cancer J Clin (2020) 70:7-30. doi: 10.3322/caac. 21590

4. Ossio R, Roldán-Marín R, Martínez-Said H, Adams DJ, Robles-Espinoza CD. Melanoma: a global perspective. Nat Rev Cancer (2017) 17:393-4. doi: $10.1038 /$ nrc.2017.43

5. Luke JJ, Flaherty KT, Ribas A, Long GV. Targeted agents and immunotherapies: optimizing outcomes in melanoma. Nat Rev Clin Oncol (2017) 14:463-82. doi: 10.1038/nrclinonc.2017.43

6. Gordon R. Skin cancer: An overview of epidemiology and risk factors. Semin Oncol Nurs (2013) 29:160-9. doi: 10.1016/j.soncn.2013.06.002

7. Dika E, Scarfi F, Ferracin M, Broseghini E, Marcelli E, Bortolani B, et al. Basal Cell Carcinoma : A Comprehensive Review. Int J Mol Sci (2020) 21:1-11. doi: 10.3390/ijms21155572

8. Lazar AD, Dinescu S, Costache M. Deciphering the Molecular Landscape of Cutaneous Squamous Cell Carcinoma for Better Diagnosis and Treatment. J Clin Med (2020) 9:1-23. doi: 10.3390/jcm9072228

9. Corchado-cobos R, Garcia-Sancha N, Gonzalez-Sarmiento R, Perez-Losada J, Cañueto J. Cutaneous Squamous Cell Carcinoma : From Biology to Therapy. Int J Mol Sci (2020) 21:1-23. doi: 10.3390/ijms21082956

10. Thompson JF, Scolyer RA, Kefforf RF. Cutaneous melanoma. Lancet (2005) 365:687-701. doi: 10.3769/radioisotopes.64.115

11. Narayanan DL, Saladi RN, Fox JL. Ultraviolet radiation and skin cancer. Int J Dermatol (2010) 49:978-86. doi: 10.1111/j.1365-4632.2010.04474.x

12. Meeran SM, Punathil T, Katiyar SK. IL-12 deficiency exacerbates inflammatory responses in UV-irradiated skin and skin tumors. J Invest Dermatol (2008) 128:2716-27. doi: 10.1038/jid.2008.140

13. Khosravi A, Jayaram B, Goliaei B, Masoudi-nejad A. Active repurposing of drug candidates for melanoma based on GWAS, PheWAS and a wide range of omics data. Mol Med (2019) 25:1-11. doi: 10.1186/s10020-019-0098-x

14. Antoszczak M, Markowska A, Markowska J, Huczyński A. Old wine in new bottles: Drug repurposing in oncology. Eur J Pharmacol (2020) 866:1-28. doi: 10.1016/j.ejphar.2019.172784

15. Shim JS, Liu JO. Recent Advances in Drug Repositioning for the Discovery of New Anticancer Drugs. Int J Biol Sci (2014) 10:654-63. doi: 10.7150/ijbs.9224 respect, several nanoformulations can enhance the efficacy of drugs to treat cancer; thus, this approach will allow well-known drugs to be used to treat skin cancer. Although nanosystems for skin cancer are not commercially available, several formulations have been proposed as nanocarriers to effectively deliver known antineoplastic therapeutic agents for skin cancers $(102,103)$.

\section{AUTHOR CONTRIBUTIONS}

HC and GL-G conceived the article. HC, OR-H, SA-A, SB-C, GF-G, and GL-G wrote the first draft of the manuscript. MG-T, MG-C, IC-F, and JS-R contributed to the discussion and the search for information. HC, MG-T, MG-C, JS-R, and GL-G critically reviewed the manuscript and edited the final version. IC-F elaborated the Table 1. All authors contributed to the article and approved the submitted version.

16. Talevi A, Bellera CL. Challenges and opportunities with drug repurposing: finding strategies to find alternative uses of therapeutics. Expert Opin Drug Discov (2020) 15:397-401. doi: 10.1080/17460441.2020.1704729

17. Gns HS, Gr S, Murahari M, Krishnamurthy M. An update on Drug Repurposing: Re-written saga of the drug's fate. BioMed Pharmacother (2019) 110:700-16. doi: 10.1016/j.biopha.2018.11.127

18. Langedijk J, Mantel-teeuwisse AK, Slijkerman DS, Schutjens M-HDB. Drug repositioning and repurposing : terminology and definitions in literature. Drug Discov Today (2015) 20:1027-34. doi: 10.1016/j.drudis.2015.05.001

19. Patel K, Doudican NA, Schiff PB, Orlow SJ. Albendazole sensitizes cancer cells to ionizing radiation. Radiat Oncol (2011) 6:1-7. doi: 10.1186/1748717X-6-160

20. Ripoll GV, Farina HG, Yoshiji H, Gomez DE, Alonso DF. Desmopressin reduces melanoma lung metastasis in transgenic mice overexpressing tissue inhibitor of metalloproteinases-1. In Vivo (2006) 20:881-5.

21. Eskiocak U, Ramesh V, Gill JG, Zhao Z, Yuan SW, Wang M, et al. Synergistic effects of ion transporter and MAP kinase pathway inhibitors in melanoma. Nat Commun (2016) 7:1-19. doi: 10.1038/ncomms12336

22. Rok J, Karkoszka M, Rzepka Z, Respondek M, Banach K, Beberok A, et al. Cytotoxic and proapoptotic effect of doxycycline - An in vitro study on the human skin melanoma cells. Toxicol In Vitro (2020) 65:104790. doi: $10.1016 /$ j.tiv.2020.104790

23. Shieh J-M, Huang T-F, Hung C-F, Chou K-H, Tsai Y-J, Wu W-B. Activation of c-Jun $\mathrm{N}$-terminal kinase is essential for mitochondrial membrane potential change and apoptosis induced by doxycycline in melanoma cells. Br J Pharmacol (2010) 160:1171-84. doi: 10.1111/j.1476-5381.2010.00746.x

24. Grabacka M, Plonka PM, Urbanska K, Reiss K. Peroxisome proliferatoractivated receptor alpha activation decreases metastatic potential of melanoma cells in vitro via down-regulation of Akt. Clin Cancer Res (2006) 12:3028-36. doi: 10.1158/1078-0432.CCR-05-2556

25. Č́ňová K, Rozkydalová L, Vokurková D, Rudolf E. Flubendazole induces mitotic catastrophe and apoptosis in melanoma cells. Toxicol In Vitro (2018) 46:313-22. doi: 10.1016/j.tiv.2017.10.025

26. Riedel T, Demaria O, Zava O, Joncic A, Gilliet M, Dyson PJ. Drug Repurposing Approach Identifies a Synergistic Drug Combination of an Antifungal Agent and an Experimental Organometallic Drug for Melanoma Treatment. Mol Pharm (2018) 15:116-26. doi: 10.1021/acs.molpharmaceut.7b00764

27. Liang G, Liu M, Wang Q, Shen Y, Mei H, Li D, et al. Itraconazole exerts its anti-melanoma effect by suppressing Hedgehog, Wnt, and PI3K/mTOR signaling pathways. Oncotarget (2017) 8:28510-25. doi: 10.18632/ oncotarget.15324

28. Hanson K, Robinson SD, Al-Yousuf K, Hendry AE, Sexton DW, Sherwood V, et al. The anti-rheumatic drug, leflunomide, synergizes with MEK inhibition to suppress melanoma growth. Oncotarget (2017) 9:3815-29. doi: 10.18632/ oncotarget. 23378 
29. Raff AB, Thomas CN, Chuang GS, Avram MM, Le MH, Anderson RR, et al. Lidocaine-induced potentiation of thermal damage in skin and carcinoma cells. Lasers Surg Med (2019) 51:88-94. doi: 10.1002/ $1 \mathrm{sm} .23027$

30. Doudican N, Rodriguez A, Osman I, Orlow SJ. Mebendazole induces apoptosis via Bcl-2 inactivation in chemoresistant melanoma cells. Mol Cancer Res (2008) 6:1308-15. doi: 10.1158/1541-7786.MCR-07-2159

31. Tomic T, Botton T, Cerezo M, Robert G, Luciano F, Puissant A, et al. Metformin inhibits melanoma development through autophagy and apoptosis mechanisms. Cell Death Dis (2011) 2:e199. doi: 10.1038/ cddis. 2011.86

32. Jaune E, Rocchi S. Metformin: Focus on Melanoma. Front Endocrinol (Lausanne) (2018) 9:472. doi: 10.3389/fendo.2018.00472

33. González Maglio DH, Paz ML, Ferrari A, Weill FS, Nieto J, Leoni J. Alterations in skin immune response throughout chronic UVB irradiation-skin cancer development and prevention by naproxen. Photochem Photobiol (2010) 86:146-52. doi: 10.1111/j.1751-1097.2009. 00623.x

34. Zhu Y, Zuo W, Chen L, Bian S, Jing J, Gan C, et al. Repurposing of the antihelminthic drug niclosamide to treat melanoma and pulmonary metastasis via the STAT3 signaling pathway. Biochem Pharmacol (2019) 169:1-10. doi: 10.1016/j.bcp.2019.08.012

35. Surjana D, Halliday GM, Damian DL. Nicotinamide enhances repair of ultraviolet radiation-induced DNA damage in human keratinocytes and ex vivo skin. Carcinogenesis (2013) 34:1144-9. doi: 10.1093/carcin/bgt017

36. Jia H, Ren W, Feng Y, Wei T, Guo M, Guo J, et al. The enhanced antitumour response of pimozide combined with the IDO inhibitor L-MT in melanoma. Int J Oncol (2018) 53:949-60. doi: 10.3892/ijo.2018.4473

37. Micali G, Lacarrubba F, Bhatt K, Nasca MR. Medical approaches to nonmelanoma skin cancer. Expert Rev Anticancer Ther (2013) 13:1409-21. doi: $10.1586 / 14737140.2013 .856759$

38. Campione E, Diluvio L, Paternò EJ, Chimenti S. Topical treatment of actinic keratoses with piroxicam $1 \%$ gel: a preliminary open-label study utilizing a new clinical score. Am J Clin Dermatol (2010) 11:45-50. doi: 10.2165/ 11311170-000000000-00000

39. De Giorgi V, Grazzini M, Benemei S, Marchionni N, Botteri E, Pennacchioli E, et al. Propranolol for Off-label Treatment of Patients With Melanoma: Results From a Cohort Study. JAMA Oncol (2018) 4:1-4. doi: 10.1001/ jamaoncol.2017.2908

40. Shi X, Li H, Shi A, Yao H, Ke K, Dong C, et al. Discovery of rafoxanide as a dual CDK4/6 inhibitor for the treatment of skin cancer. Oncol Rep (2018) 40:1592-600. doi: 10.3892/or.2018.6533

41. Grahovac J, Srdić-Rajić T, Francisco Santibañez J, Pavlović M, Čavić M, Radulović S. Telmisartan induces melanoma cell apoptosis and synergizes with vemurafenib in vitro by altering cell bioenergetics. Cancer Biol Med (2019) 16:247-63. doi: 10.20892/j.issn.2095-3941.2018.0375

42. Eichhorn EJ, Gheorghiade M. Digoxin. Prog Cardiovasc Dis (2002) 44:25166. doi: 10.1053/pcad.2002.31591

43. Masoud GN, Li W. HIF-1 $\alpha$ pathway: role, regulation and intervention for cancer therapy. Acta Pharm Sin B (2015) 5:378-89. doi: 10.1016/j.apsb. 2015.05.007

44. Smolarczyk R, Cichoń T, Pilny E, Jarosz-Biej M, Poczkaj A, Kułach N, et al. Combination of anti-vascular agent - DMXAA and HIF- $1 \alpha$ inhibitor digoxin inhibits the growth of melanoma tumors. Sci Rep (2018) 8:1-9. doi: 10.1038/s41598-018-25688-y

45. Frankel AE, Eskiocak U, Gill JG, Yuan S, Ramesh V, Froehlich TW, et al. Digoxin Plus Trametinib Therapy Achieves Disease Control in BRAF WildType Metastatic Melanoma Patients. Neoplasia (2017) 19:255-60. doi: 10.1016/j.neo.2017.01.010

46. Gaillard T, Briolant S, Madamet M, Pradines B. The end of a dogma: the safety of doxycycline use in young children for malaria treatment. Malar J (2017) 16:1-5. doi: 10.1186/s12936-017-1797-9

47. Gomez DE, Yoshiji H, Kim JC, Thorgeirsson UP. Ulex europaeus I lectin induces activation of matrix-metalloproteinase-2 in endothelial cells. Biochem Biophys Res Commun (1995) 216:177-82. doi: 10.1006/ bbrc. 1995.2607

48. Barbie DA, Kennedy BK. Doxycycline: new tricks for an old drug. Oncotarget (2015) 6:19336-7. doi: 10.18632/oncotarget.5111
49. Lamb R, Ozsvári B, Lisanti C, Tanowitz H, Howell A, Martinez-Outschoorn $\mathrm{U}$, et al. Antibiotics that target mitochondria effectively eradicate cancer stem cells, across multiple tumor types: Treating cancer like an infectious disease. Oncotarget (2015) 6:1-16. doi: 10.18632/oncotarget.3174

50. Alexander-Savino CV, Hayden MS, Richardson C, Zhao J, Poligone B. Doxycycline is an NF- $\mathrm{KB}$ inhibitor that induces apoptotic cell death in malignant T-cells. Oncotarget (2016) 7:75954-67. doi: 10.18632/ oncotarget. 12488

51. Sun T, Zhao N, Ni C, Zhao X, Zhang W, Su X, et al. Doxycycline inhibits the adhesion and migration of melanoma cells by inhibiting the expression and phosphorylation of focal adhesion kinase (FAK). Cancer Lett (2009) 285:141-50. doi: 10.1016/j.canlet.2009.05.004

52. McKeage K, Keating GM. Fenofibrate: a review of its use in dyslipidaemia. Drugs (2011) 71:1917-46. doi: 10.2165/11208090-000000000-00000

53. Shigeto T, Yokoyama Y, Xin B, Mizunuma H. Peroxisome proliferatoractivated receptor alpha and gamma ligands inhibit the growth of human ovarian cancer. Oncol Rep (2007) 18:833-40. doi: 10.3892/or.18.4.833

54. Li T, Zhang Q, Zhang J, Yang G, Shao Z, Luo J, et al. Fenofibrate induces apoptosis of triple-negative breast cancer cells via activation of NF- $\mathrm{\kappa B}$ pathway. BMC Cancer (2014) 14:1-13. doi: 10.1186/1471-2407-14-96

55. Grabacka M, Placha W, Plonka PM, Pajak S, Urbanska K, Laidler P, et al. Inhibition of melanoma metastases by fenofibrate. Arch Dermatol Res (2004) 296:54-8. doi: 10.1007/s00403-004-0479-y

56. Panigrahy D, Kaipainen A, Huang S, Butterfield CE, Barnés CM, Fannon M, et al. PPAR $\alpha$ agonist fenofibrate suppresses tumor growth through direct and indirect angiogenesis inhibition. Proc Natl Acad Sci (2008) 105:985-90. doi: 10.1073/pnas.0711281105

57. Dana N, Haghjooy Javanmard S, Vaseghi G. The effect of fenofibrate, a PPAR $\alpha$ activator on toll-like receptor- 4 signal transduction in melanoma both in vitro and in vivo. Clin Transl Oncol (2020) 22:486-94. doi: 10.1007/ s12094-019-02150-7

58. Feldmeier H, Bienzle U, Döhring E, Dietrich M. Flubendazole versus mebendazole in intestinal helminthic infections. Acta Trop (1982) 39:1859. doi: 10.5169/SEALS-312976

59. Čáňová K, Rozkydalová L, Rudolf E. Anthelmintic Flubendazole and Its Potential Use in Anticancer Therapy. Acta Med (Hradec Kralove) (2017) 60:5-11. doi: 10.14712/18059694.2017.44

60. Li Y, Acharya G, Elahy M, Xin H, Khachigian LM. The anthelmintic flubendazole blocks human melanoma growth and metastasis and suppresses programmed cell death protein-1 and myeloid-derived suppressor cell accumulation. Cancer Lett (2019) 459:268-76. doi: 10.1016/j.canlet.2019.05.026

61. Rudolf K, Rudolf E. An analysis of mitotic catastrophe induced cell responses in melanoma cells exposed to flubendazole. Toxicol In Vitro (2020) 68:104930. doi: 10.1016/j.tiv.2020.104930

62. Kim J, Tang JY, Gong R, Kim J, Lee JJ, Clemons KV, et al. Itraconazole, a commonly used antifungal that inhibits Hedgehog pathway activity and cancer growth. Cancer Cell (2010) 17:388-99. doi: 10.1016/j.ccr.2010.02.027

63. Kim DJ, Kim J, Spaunhurst K, Montoya J, Khodosh R, Chandra K, et al. Open-label, exploratory phase II trial of oral itraconazole for the treatment of basal cell carcinoma. J Clin Oncol (2014) 32:745-51. doi: 10.1200/ JCO.2013.49.9525

64. Schiff MH, Strand V, Oed C, Loew-Friedrich I. Leflunomide: efficacy and safety in clinical trials for the treatment of rheumatoid arthritis. Drugs Today (Barc) (2000) 36:383-94. doi: 10.1358/dot.2000.36.6.584259

65. Breedveld FC, Dayer JM. Leflunomide: mode of action in the treatment of rheumatoid arthritis. Ann Rheum Dis (2000) 59:841-9. doi: 10.1136/ ard.59.11.841

66. Zhang C, Chu M. Leflunomide: A promising drug with good antitumor potential. Biochem Biophys Res Commun (2018) 496:726-30. doi: 10.1016/ j.bbrc.2018.01.107

67. White RM, Cech J, Ratanasirintrawoot S, Lin CY, Rahl PB, Burke CJ, et al. DHODH modulates transcriptional elongation in the neural crest and melanoma. Nature (2011) 471:518-22. doi: 10.1038/nature09882

68. O'Donnell EF, Kopparapu PR, Koch DC, Jang HS, Phillips JL, Tanguay RL, et al. The aryl hydrocarbon receptor mediates leflunomide-induced growth inhibition of melanoma cells. PLoS One (2012) 7:e40926. doi: 10.1371/ journal.pone.0040926 
69. Liu L, Dong Z, Lei Q, Yang J, Hu H, Li Q, et al. Inactivation/deficiency of DHODH induces cell cycle arrest and programed cell death in melanoma. Oncotarget (2017) 8:112354-70. doi: 10.18632/oncotarget.19379

70. Dayan AD. Albendazole, mebendazole and praziquantel. Review of nonclinical toxicity and pharmacokinetics. Acta Trop (2003) 86:141-59. doi: 10.1016/s0001-706x(03)00031-7

71. Guerini AE, Triggiani L, Maddalo M, Bonù ML, Frassine F, Baiguini A, et al. Mebendazole as a Candidate for Drug Repurposing in Oncology: An Extensive Review of Current Literature. Cancers (Basel) (2019) 11:1-22. doi: 10.3390/cancers11091284

72. Doudican NA, Byron SA, Pollock PM, Orlow SJ. XIAP downregulation accompanies mebendazole growth inhibition in melanoma xenografts. Anticancer Drugs (2013) 24:181-8. doi: 10.1097/CAD.0b013e32835a43f1

73. Doudican NA, Pennell R, Byron S, Pollock P, Liebes L, Osman I, et al. Mebendazole in the treatment of melanoma: The role of Bcl-2 in predicting response and enhancing efficacy. J Clin Oncol (2010) 28:e19021-1. doi: 10.1200/jco.2010.28.15_suppl.e19021

74. Simbulan-Rosenthal CM, Dakshanamurthy S, Gaur A, Chen Y-S, Fang H-B, Abdussamad M, et al. The repurposed anthelmintic mebendazole in combination with trametinib suppresses refractory NRASQ61K melanoma. Oncotarget (2017) 8:12576-95. doi: 10.18632/oncotarget.14990

75. Nasri H, Rafieian-Kopaei M. Metformin: Current knowledge. J Res Med Sci (2014) 19:658-64.

76. Haq R. Metabolic dysregulation in melanoma: cause or consequence? Cancer Discov (2014) 4:390-1. doi: 10.1158/2159-8290.CD-14-0173

77. Tseng C-H. Metformin is associated with decreased skin cancer risk in Taiwanese patients with type 2 diabetes. J Am Acad Dermatol (2018) 78:694700. doi: 10.1016/j.jaad.2017.12.016

78. Chaudhary SC, Kurundkar D, Elmets CA, Kopelovich L, Athar M. Metformin, an antidiabetic agent reduces growth of cutaneous squamous cell carcinoma by targeting mTOR signaling pathway. Photochem Photobiol (2012) 88:1149-56. doi: 10.1111/j.1751-1097.2012.01165.x

79. Li K, Zhang T-T, Wang F, Cui B, Zhao C-X, Yu J-J, et al. Metformin suppresses melanoma progression by inhibiting KAT5-mediated SMAD3 acetylation, transcriptional activity and TRIB3 expression. Oncogene (2018) 37:2967-81. doi: 10.1038/s41388-018-0172-9

80. Tseng H-W, Li S-C, Tsai K-W. Metformin Treatment Suppresses Melanoma Cell Growth and Motility Through Modulation of microRNA Expression. Cancers (Basel) (2019) 11:1-20. doi: 10.3390/cancers11020209

81. Pereira FV, Melo ACL, Low JS, de Castro ÍA, Braga TT, Almeida DC, et al. Metformin exerts antitumor activity via induction of multiple death pathways in tumor cells and activation of a protective immune response. Oncotarget (2018) 9:25808-25. doi: 10.18632/oncotarget.25380

82. Cerezo M, Tichet M, Abbe P, Ohanna M, Lehraiki A, Rouaud F, et al. Metformin blocks melanoma invasion and metastasis development in AMPK/p53-dependent manner. Mol Cancer Ther (2013) 12:1605-15. doi: 10.1158/1535-7163.MCT-12-1226-T

83. Ryabaya O, Prokofieva A, Akasov R, Khochenkov D, Emelyanova M, Burov S, et al. Metformin increases antitumor activity of MEK inhibitor binimetinib in 2D and 3D models of human metastatic melanoma cells. BioMed Pharmacother (2019) 109:2548-60. doi: 10.1016/j.biopha.2018.11.109

84. Naguy A. Pimozide: An Old Wine in a New Bottle! Indian J Psychol Med (2017) 39:382-3. doi: 10.4103/IJPSYM.IJPSYM_400_16

85. Choi J, Lee Y-J, Yoon YJ, Kim C-H, Park S-J, Kim S-Y, et al. Pimozide suppresses cancer cell migration and tumor metastasis through binding to ARPC2, a subunit of the Arp2/3 complex. Cancer Sci (2019) 110:3788-801. doi: 10.1111/cas.14205

86. Neifeld JP, Tormey DC, Baker MA, Meyskens FLJ, Taub RN. Phase II trial of the dopaminergic inhibitor pimozide in previously treated melanoma patients. Cancer Treat Rep (1983) 67:155-7.

87. Zhao T, Wei T, Guo J, Wang Y, Shi X, Guo S, et al. PD-1-siRNA delivered by attenuated Salmonella enhances the antimelanoma effect of pimozide. Cell Death Dis (2019) 10:164. doi: 10.1038/s41419-019-1418-3

88. Jia H, Guo J, Wang P, Sun K, Chen J, Ren W, et al. A self-designed CpG ODN enhanced the anti-melanoma effect of pimozide. Int Immunopharmacol (2020) 83:106397. doi: 10.1016/j.intimp.2020.106397

89. Mostafa GAE, Al-Dosseri AS, Al-Badr AA. Piroxicam. Profiles Drug Subst Excip Relat Methodol (2020) 45:199-474. doi: 10.1016/bs.podrm.2019.10.007
90. Asgari M, White E, Chren M-M. Nonsteroidal anti-inflammatory drug use in the prevention and treatment of squamous cell carcinoma. Dermatol Surg (2004) 30:1335-42. doi: 10.1111/j.1524-4725.2004.30407.x

91. Campione E, Paternò EJ, Candi E, Falconi M, Costanza G, Diluvio L, et al. The relevance of piroxicam for the prevention and treatment of nonmelanoma skin cancer and its precursors. Drug Des Devel Ther (2015) 9:5843-50. doi: 10.2147/DDDT.S84849

92. Agozzino M, Russo T, Franceschini C, Mazzilli S, Garofalo V, Campione E, et al. Effects of topical piroxicam and sun filters in actinic keratosis evolution and field cancerization: a two-center, assessor-blinded, clinical, confocal microscopy and dermoscopy evaluation trial. Curr Med Res Opin (2019) 35:1785-92. doi: 10.1080/03007995.2019.1626227

93. Babino G, Diluvio L, Bianchi L, Orlandi A, Di Prete M, Chimenti S, et al. Longterm use of a new topical formulation containing piroxicam $0.8 \%$ and sunscreen: efficacy and tolerability on actinic keratosis. A proof of concept study. Curr Med Res Opin (2016) 32:1345-9. doi: 10.1080/03007995.2016.1174678

94. Mazzilli S, Garofalo V, Ventura A, Diluvio L, Milani M, Bianchi L, et al. Effects of topical $0.8 \%$ piroxicam and $50+$ sunscreen filters on actinic keratosis in hypertensive patients treated with or without photosensitizing diuretic drugs: an observational cohort study. Clin Cosmet Invest Dermatol (2018) 11:485-90. doi: 10.2147/CCID.S178386

95. Garofalo V, Ventura A, Mazzilli S, Diluvio L, Bianchi L, Toti L, et al. Treatment of Multiple Actinic Keratosis and Field of Cancerization with Topical Piroxicam $0.8 \%$ and Sunscreen 50+ in Organ Transplant Recipients: A Series of 10 Cases. Case Rep Dermatol (2017) 9:211-6. doi: 10.1159/ 000481770

96. Puviani M, Galloni C, Marchetti S, Sergio Pavone P, Lovati S, Pistone G, et al. Efficacy of a film-forming medical device containing sunscreen (50+) and piroxicam $0.8 \%$ in actinic keratosis and field cancerization: a multicenter, assessor-blinded, 3 month trial. Curr Med Res Opin (2017) 33:1255-9. doi: 10.1080/03007995.2017.1313212

97. Scotti E, Deledda S, Milani M. Efficacy of a Film-Forming Medical Device Containing Piroxicam and Sun Filters in the Treatment of Multiple Actinic Keratosis Lesions in a Subject with a History of Kaposi Sarcoma. Case Rep Dermatol (2016) 8:254-61. doi: 10.1159/000450723

98. Khodaie F, Khazaei-poul Y, Moini Zanjani T. Anti-Proliferative Effects of Piroxicam and Nimesulide on A431 Human Squamous Carcinoma Cell Line. Int J Cancer Manag (2017) 10:1-5. doi: 10.5812/ijcm.7565

99. Chiu LCM, Tong KF, Ooi VEC. Cytostatic and cytotoxic effects of cyclooxygenase inhibitors and their synergy with docosahexaenoic acid on the growth of human skin melanoma A-375 cells. BioMed Pharmacother (2005) 59(Suppl 2):S293-7. doi: 10.1016/s0753-3322(05)80049-6

100. Kirtonia A, Gala K, Fernandes SG, Pandya G, Pandey AK, Sethi G, et al. Repurposing of drugs: An attractive pharmacological strategy for cancer therapeutics. Semin Cancer Biol (2020). doi: 10.1016/j.semcancer.2020.04.006

101. Lionta E, Spyrou G, Vassilatis DK, Cournia Z. Structure-based virtual screening for drug discovery: principles, applications and recent advances. Curr Top Med Chem (2014) 14:1923-38. doi: 10.2174/1568026614666140929124445

102. Borgheti-Cardoso LN, Viegas JSR, Silvestrini AVP, Caron AL, Praça FG, Kravicz $\mathrm{M}$, et al. Nanotechnology approaches in the current therapy of skin cancer. $A d v$ Drug Deliv Rev (2020) 153:109-36. doi: 10.1016/j.addr.2020.02.005

103. Akhtar N, Khan RA. Liposomal systems as viable drug delivery technology for skin cancer sites with an outlook on lipid-based delivery vehicles and diagnostic imaging inputs for skin conditions'. Prog Lipid Res (2016) 64:192230. doi: $10.1016 /$ j.plipres.2016.08.005

Conflict of Interest: The authors declare that the research was conducted in the absence of any commercial or financial relationships that could be construed as a potential conflict of interest.

Copyright (c) 2021 Cortés, Reyes-Hernández, Alcalá-Alcalá, Bernal-Chávez, Caballero-Florán, González-Torres, Sharifi-Rad, González-Del Carmen, Figueroa-González and Leyva-Gómez. This is an open-access article distributed under the terms of the Creative Commons Attribution License (CC BY). The use, distribution or reproduction in other forums is permitted, provided the original author(s) and the copyright owner(s) are credited and that the original publication in this journal is cited, in accordance with accepted academic practice. No use, distribution or reproduction is permitted which does not comply with these terms. 